\title{
Kajian Kasus: Periodontitis Kronis pada Pasien dengan Riwayat Diabetes Melitus
}

\author{
(Case Study: Chronic Periodontitis in Patients with a History of Diabetes Mellitus)
}

Aris Aji Kurniawan ${ }^{1 *}$, Anis Sevia Pramaeswari ${ }^{2}$, Anindita Laksitasari ${ }^{1}$

1 Bagian IImu Penyakit Mulut Jurusan Kedokteran Gigi Fakultas Kedokteran Universitas Jenderal Soedirman, Purwokerto, Indonesia

2 Program Profesi Dokter Gigi, Universitas Jenderal Soedirman, Purwokerto, Indonesia

\begin{abstract}
Abstrak
Peridontitis kronis merupakan suatu penyakit inflamasi yang terjadi pada jaringan periodontal. Penyebab periodontitis kronis dapat adalah faktor lokal dan sistemik. Faktor lokal yang dapat mengakibatkan periodontitis kronis adalah akumulasi plak, sedangkan faktor sistemik dapat berupa penyakit sistemik seperti penyakit diabetes melitus. Tujuan laporan kasus adalah menjelaskan kondisi periodontitis kronis yang terjadi pada pasien dengan penyakit diabetes melitus. Seorang wanita berusia 52 tahun mengeluhkan gigi-geliginya goyang sejak sekitar satu tahun terakhir. Pasien diketahui memiliki riwayat penyakit diabetes melitus dan sedang menjalani pengobatan rutin. Pemeriksaan klinis pada rongga mulut menunjukkan adanya resesi gingiva pada area gigi anterior dan posterior baik maksila maupun mandibula, disertai kegoyahan gigi-geligi. Pasien dengan kondisi diabetes melitus mengalami penurunan respon imun dan fungsi sel. Kondisi ini dapat menghambat proses perbaikan jaringan dan destruksi bakteri, sehingga dapat meningkatkan derajat keparahan kondisi periodontal. Sebaliknya, kondisi periodontitis juga dapat berpengaruh terhadap keparahan diabetes melitus. Penyakit periodontitis dan diabetes melitus memiliki hubungan yang saling mempengaruhi keparahan masing-masing.
\end{abstract}

Kata kunci: Diabetes Melitus, Distruksi Bakteria, Plak, Periodontitis kronis

\section{Abstract}

Chronic periodontitis is an inflammatory disease that occurs in periodontal tissue. The causes of chronic periodontitis can be local and systemic factors. Local factors that can cause chronic periodontitis are plaque accumulation, while systemic factors can be in the form of systemic diseases such as diabetes mellitus. The purpose was to explain the condition of chronic periodontitis that occurs in patients with diabetes mellitus. A 52-year-old woman complained that her teeth have been rocking for about a year. The patient is known to have a history of diabetes mellitus and is undergoing routine treatment. Clinical examination of the oral cavity shows gingival recession in the anterior and posterior teeth area of both the maxilla and mandible, accompanied by the shakiness of the teeth. Patients with diabetes mellitus have decreased immune response and cell function. This condition can inhibit the process of tissue repair and bacterial destruction, to increase the severity of periodontal conditions. the condition of periodontitis can also affect the severity of diabetes mellitus. Conclusion: Periodontitis and diabetes mellitus have a mutually influential relationship.

Keywords: Bacterial Destruction, Chronic Periodontitis, Diabetes Mellitus, Plaque

Korespondensi (Correspondence) : Aris Aji Kurniawan, Bagian Ilmu Penyakit Mulut, Jurusan Kedokteran Gigi, Fakultas Kedokteran. Jl. Dr. Soeparno, Kampus Karangwangkal Gedung E, Karang Bawang, Grendeng, Kec. Purwokerto Utara, Kabupaten Banyumas, Jawa Tengah 53122. Email: arisajikurniawan@gmail.com.

Periodontitis kronis merupakan penyakit jaringan periodontal yang disebabkan oleh sekelompok mikroorganisme spesifik, sehingga mengakibatkan kerusakan ligamen periodontal dan tulang alveolar dengan membentuk poket, resesi gingiva, atau keduanya. ${ }^{1}, 2$ Periodontitis kronis ditandai dengan pergeseran epitel jungsional ke arah apikal, kehilangan perlekatan, dan resorpsi tulang alveolar.' Penyakit ini mengakibatkan gangguan fungsi pengunyahan dan hilangnya gigi geligi. ${ }^{3}$

Periodontitis kronis dapat disebabkan oleh faktor lokal dan sistemik.' Faktor lokal berupa akumulasi plak pada permukaan gigi yang mengandung kumpulan bakteri seperti bakteri

Actinobacillus actinomycetemcomitans, Porphyromonas gingivalis, Tannarella forsythia, Fusobacterium nucleatum, Prevotella intermedia, Treponema, Campylobacter rectus, Eikenella corrodens, Peptostreptococcus micros, dan spesies Eubacterium. ${ }^{12}$ Produk bakteri ini menyebabkan terjadinya kerusakan jaringan gingiva dan menghilangkan perlekatan gingiva. 4,12 Faktor sistemik dapat memperparah kondisi periodontitis kronis, meliputi perubahan hormon, stres, dan penyakit sistemik. Salah satu penyakit sistemik yang dapat mempengaruhi terjadinya periodontitis kronis adalah diabetes melitus. ${ }^{5}$

Diabetes melitus merupakan penyakit gangguan metabolik ditandai dengan adanya peningkatan kadar gula dalam darah akibat adanya kelainan sekresi insulin oleh sel $\beta$ pankreas, kerja insulin, maupun kombinasi keduanya. ${ }^{8}$ Diabetes melitus (DM) memiliki dua tipe, yaitu tipe 1 dan tipe 2. DM tipe 1 terjadi akibat kelenjar pankreas tidak dapat memproduksi insulin, mengakibatkan jumlah insulin tidak mencukupi kebutuhan tubuh, sedangkan pada penyakit DM tipe 2, 
pankreas dapat memproduksi insulin dengan jumlah yang cukup, tetapi insulin tidak dapat berfungsi dengan baik. ${ }^{7}$ Manifestasi klinis yang ditemukan pada pasien dengan diabetes melitus antara lain polidipsia, poliuria, dan polifagia. Sedangkan manifestasi klinis pada rongga mulut yang dapat terjadi ketika mengalami DM antara lain xerostomia, gingivitis, periodontitis kronis, burning mouth sensation, oral thrush, dan stomatitis. ${ }^{13}$ Jurnal ini bertujuan untuk memaparkan kondisi periodontitis kronis pada penderita diabetes melitus.

\section{LAPORAN KASUS}

Seorang wanita berusia 52 tahun datang ke RSGM Unsoed dengan keluhan gigi-geligi yang goyang sejak sekitar satu tahun terakhir. Pasien memiliki riwayat diabetes melitus dan sedang menjalani pengobatan. Namun pasien tidak rutin mengkonsumsi obat dan tidak rutin mengecek kadar gula dalam darah. Pasien lebih memilih untuk menjaga pola makan agar kadar gula dalam darah tidak tinggi. Kelvarga pasien diketahui memiliki riwayat diabetes melitus. Hasil pemeriksaan kadar gula darah dalam beberapa bulan terakhir adalah sebagai berikut (Tabel 1 terlampir)

Pemeriksaan klinis pada rongga mulut pasien menunjukkan adanya warna kemerahan pada gingiva bagian lingual gigi anterior dan resesi gingiva (Gambar 1). Resesi gingiva terjadi hampir di seluruh gigi, baik pada gigi rahang atas maupun rahang bawah. Pemeriksaan klinis menunjukkan adanya kehilangan perlekatan dan luksasi gigi $17,22,26,33,32,31,41$, dan 44 . Terdapat akumulasi kalkulus pada lingual gigi anterior rahang bawah. Hasil pemeriksaan penunjang berupa radiografi panoramik menunjukkan adanya penurunan tulang alveolar secara horizontal pada rahang atas dan rahang bawah. Gigi anterior dan posterior rahang atas dan rahang bawah kehilangan tulang alveolar mencapai 1/3 apikal (Gambar 2).

Tabel 1. Hasil Pemeriksaan Glukosa

\begin{tabular}{lc}
\hline Bulan & $\begin{array}{c}\text { Gula Darah Sewaktu } \\
(\mathrm{mg} / \mathrm{dl})\end{array}$ \\
\hline September 2018 & 249 \\
Februari 2019 & 262 \\
April 2019 & 149 \\
\hline
\end{tabular}

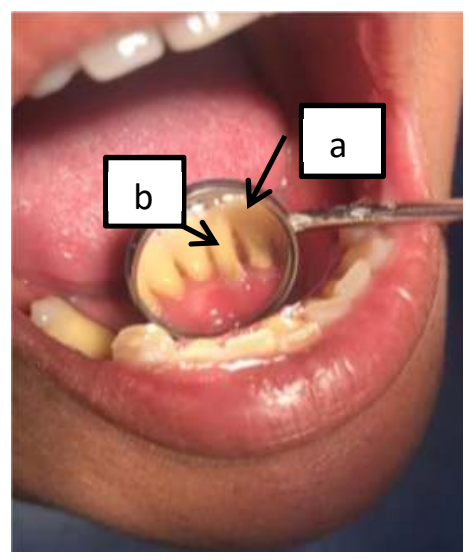

Gambar 1. Foto klinis pasien. Resesi gingiva (a); warna kemerahan pada gingiva (b).

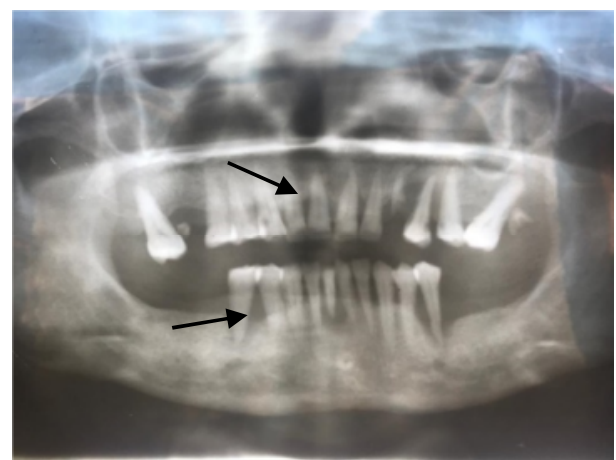

Gambar 2. Radiografi periapikal pasien. Terdapat penurunan tulang alveolar secara horizontal. 


\section{PEMBAHASAN}

Diabetes melitus merupakan kumpulan gejala (sindrom metabolik) yang terjadi karena tubuh mengalami gangguan metabolisme dalam mengontrol gula darah. Menurut American Diabetes Association (ADA) (2010), kriteria diagnosis diabetes melitus, yaitu apabila kadar gula darah (glukosa) sewaktu $\geq 200 \mathrm{mg} / \mathrm{dll}(11,1 \mathrm{mmol} / \mathrm{L})$, kadar glukosa darah saat puasa $\geq 126 \mathrm{mg} / \mathrm{dl}$ $(7.0 \mathrm{mmol} / \mathrm{L})$, dan kadar glukosa darah 2 jam $\mathrm{PP} \geq 200 \mathrm{mg} / \mathrm{dl}(11,1 \mathrm{mmol} / \mathrm{L})$. Glukosa darah sewaktu merupakan hasil pemeriksaan sesaat tanpa memperhatikan waktu makan terakhir. Kadar glukosa darah puasa diukur dalam kondisi pasien tidak mendapat kalori sedikitnya 8 jam. Pemeriksaan kadar gula darah ini penting untuk mengatur terapi dalam pengendalian gula darah secara optimal dan mengetahui toleransi tubuh terutama insulin terhadap pemberian glukosa dari waktu ke waktu. ${ }^{7}$

Periodontitis kronis merupakan salah satu dari enam komplikasi diabetes melitus. Enam komplikasi tersebut meliputi nefropati, retinopati, neuropati, penyakit makrovaskular, periodontitis, dan penyembuhan luka yang buruk." Pemeriksaan klinis pada kasus ini menunjukkan pergeseran margin gingiva ke arah apikal atau resesi gingiva, serta terjadi kehilangan perlekatan antara gingiva dan gigi. Berdasarkan hal tersebut, dapat diketahui bahwa pasien dalam kasus ini memiliki kondisi periodontitis akibat komplikasi dari diabetes melitus. Penelitian Bridges dkk. (2003) menunjukkan bahwa diabetes dapat mempengaruhi semua kesehatan periodontal, termasuk skor bleeding, probing depth, hilangnya perlekatan dan tanggalnya gigi. ${ }^{10}$

Keparahan kondisi penyakit periodontal pada pasien diabetes melitus dipengaruhi oleh penurunan respon imun. ${ }^{15}$ Penderita diabetes lebih rentan terhadap terjadinya infeksi. Hal ini diakibatkan karena terjadi polymorphonuclear (PMN) leukocyte deficiencies, sehingga menyebabkan gangguan dan hambatan pada kemotaksis, serta defek fagositosis. Pada pasien dengan diabetes yang tidak terkontrol terjadi pula gangguan pada fungsi PMN dan monosit serta makrofag yang berperan sebagai pertahanan terhadap bakteri patogen. Makrofag dan monosit juga meningkatkan produksi sitokin pro inflamasi dan TNFa. Kondisi-kondisi ini dapat meningkatkan destruksi jaringan periodontal. Sintesis kolagen dari fibroblas pada pasien diabetes melitus tidak dapat berfungsi dengan baik sehingga menghambat proses perbaikan jaringan gingiva. Kolagen tersebut rentan terdegradasi oleh enzim matriks metaloproteinase. Produksi enzim matriks metaloproteinase ini mengalami peningkatan pada pasien diabetes melitus. ${ }^{14,15}$

Kondisi penurunan sistem imun tersebut beriringan dengan peningkatan ekosistem dan aktivitas bakteri pada gingiva. Penderita DM memiliki kadar glukosa yang lebih tinggi di dalam gingival crevicular fluid (GCF). Kadar glukosa juga meningkat pada saliva. Peningkatan kadar glukosa ini mempengaruhi komposisi lapisan biofilm dan plak pada permukaan gigi yang merupakan tempat perlekatan bakteri. Perlekatan bakteri akan lebih banyak sehingga aktivitas destruksi bakteri terhadap gigi dan jaringan periodontal meningkat.2,9

Pasien dengan diabetes melitus menunjukkan adanya penurunan tulang alveolar secara horizontal. Pada kasus ini secara klinis pasien menunjukkan periodontitis yang parah akibat destruksi jaringan periodontal yang berlebihan. Hal ini terjadi karena hiperglikemi pada pasien diabetes melitus menghambat proliferasi osteoblas sehingga menurunkan fungsi pembentukan tulang. Kondisi hiperglikemi juga menyebabkan protein dan molekul matriks mengalami non-enzymatic glicosylation. Kondisi ini menghasilkan advanced glycation end products (AGEs) pada jaringan. Akumulasi AGEs meningkatkan produksi sitokin proinflamasi dan TNFa, serta membuat kolagen mudah terdegradasi. ${ }^{11}$

Sintesis dan sekresi sitokin yang berasal dari interaksi antara AGEs dengan reseptor AGE (RAGE) dapat juga dipengaruhi oleh sistesis dan sekresi sitokin akibat infeksi yang berasal dari periodontitis, begitu pula sebaliknya. Hal ini menunjukkan bahwa periodontitis dan DM memiliki efek timbal balik 3,4 Oleh karena itu, penyakit periodontal yang berupa inflamasi kronis dapat memperparah status penderita diabetes melitus ke arah komplikasi yang lebih berat. Hasil penelitian menunjukkan bahwa komplikasi diabates pada diabetes melitus tipe 1 maupun tipe 2 lebih parah pada pasien diabetes dengan penyakit periodontal yang parah dibandingkan dengan pasien diabetes yang hanya menderita penyakit periodontal ringan sampai sedang. ${ }^{4}$ Periodontitis kronis yang parah pada penderita DM diduga menjadi penyebab bagi peningkatan konsentrasi hemoglobin terglikosilasi. Infeksi yang berasal dari periodontitis selain meningkatkan produksi sitokin, diduga juga dapat meningkatkan resistensi insulin yang pada akhirnya memperburuk kontrol glikemik penderita diabetes yang juga menderita periodontitis.

Perawatan yang dilakukan pada kasus ini adalah scaling dan peningkatan oral hygiene. Kerentanan terhadap kerusakan periodontal harus dijelaskan kepada pasien dan harus dilakukan scaling yang teratur dan perawatan kebersihan mulut yang rutin. Pemeriksaan gigi dan mulut setiap tahun bagi pasien DM perlu dilakukan agar dapat diketahui diagnosis penyakit mulut yang lebih awal. Beberapa penelitian menunjukkan pengendalian diabetes melitus untuk memperbaiki kondisi penyakit jaringan periodontal telah banyak dilalukan. Penyakit 
periodontal dengan tingkat/kadar glukosa darah pada penderita DM tipe 2, dimana tingkat keparahan penyakit periodontal semakin meningkat dengan adanya peningkatan kadar glukosa darah dan meningkatnya skor community periodontal index of treatment needs (CPITN). Almas dkk. (2003) menjelaskan bahwa efek instruksi oral hygiene pada penderita DM tipe 2 dapat memberi efek positif pada kontrol metabolik penderita di mana score fasting blood glucosa level (FBGL) dan score gingival crevicular fluid (GCF) berkurang. Penelitian dari Debora C dkk. (2003) menunjukkan terapi non surgical pada pasien DM terbukti efektif menurunkan kadar gukosa dan menurunkan parameter klinik adanya infeksi periodontal. ${ }^{10}$

Keparahan penyakit periodontal dapat dipengaruhi oleh kondisi sistemik seperti diabetes melitus, dan sebaliknya periodontitis juga dapat berpengaruh terhadap keparahan diabetes melitus. Hal itu berkaitan dengan penurunan respon imun pasien. Oleh karena itu, perlu dilakukan perawatan rutin seperti scaling dan peningkatan oral hygiene pada penderita diabetes yang disertai periodontitis.

\section{DAFTAR PUSTAKA}

1. Acton QA. Chronic periodontitis: new insight for healthcare professional. Atlanta: Scholarly Edition; 2011.

2. Aren G, Sepet E, Ozdemir D, Dinccag N, Guvener B, Firatli E. Periodontal Health, Saliva Status, and Metabolic Control in Children with Type 1 Diabetes Mellitus, J. Periodontol, 2003; 74(12):1789-95.

3. Beck JD, Offenbacher S. The Association Between Periodontal Disease and Cardiovascular Disease: A State-OfThescience Review. Ann Periodontol, 2001; 6: 9-15.

4. Bullon $P$, Newman $H N$, Battino $M$. Obesity, Diabetes Mellitus, Atherosclerosis and Chronic Periodontitis: A Shared Pathology Via Oxidative Stress and Mitochondrial Dysfunction?. Periodontology 2000. 2014; 64: 139-53.

5. Chapple ILC, Genco R. Diabetes and Periodontal Diseases: Consensus Report of the Joint EFP/AAP Workshop on Periodontitis and Systemic Diseases.J Clin Periodontol. 2013; 40:106-12.

6. Daliemunthe SH. Hubungan Timbal Balik Antara Periodontitis dengan diabates melitus. DentikaJ Dent. 2003; 8(2): 120-5.
7. Endriana. Perbedaan Hasil Pemeriksaan Kadar Glukosa Darah 2 Jam Post Prandial Dengan Menggunakan Glukometer Dan Analyzer Pada Penderita Diabetes Melitus. Prodi D3 Analis Kesehatan UM Surabaya. 2012

8. Ford AM, Focus on Diabetes Mellitus Research. New York: Nova Science Publisher; 2006.

9. Harmanpreet K., Bhawanpreet S., Anshu S., Assessment of Blood Glucose Using Gingival Crevicular Blood in Diabetic and Non-diabetic Patients: A Chair Side Method, Journal of Clinical and Diagnostic Research, 2013; 7(12): 3066-9.

10. Hartanti. Efek Kontrol Glikemik Teradap Penyakit Periodontal Penderita Diabetes Mellitus. IDJ. 2013; 2(2): 97-102.

11. Lestari DP, Wowor VNS, Tambunan E. Hubungan tingkat pengetahuan kesehatan gigi dan mulut dengan status jaringan periodontal pada penyandang diabetes melitus di RSUD Manembonembo Bitung. Jurnal eGigi. 2016; 4: 18895.

12. Newman MG, Takei HH, Klokkevold PR, Carranza FA. Carranza's clinical periodontology 11th edition. LOS Angeles: Elsevier Saunders; 2012.

13. Ozcan S. Diabetes Mellitus: Protocol and Methods. New Jersey: Humana Press; 2003.

14. Pranckeviciene A, Siudikiene J, Ostraukas R, Machiulskiene V. Severity of periodontal disease in adlt patients with diabetes mellitus in relation to the type of diabetes. Biomed Paper Medicine. 2014; 158 (1): 117-23.

15. Stanko $\mathrm{P}$, Holla LI. Bidirectional association between diabetes mellitus and inflammatory periodontal disease. Biomed Paper Medicine. 2014; 58: 35-8.

16. Wu YY, Xiao E, Graves DT. Diabetes mellitus related bone metabolism and periodontal disease. International Journal Of Oral Science. 2015; 7: 63-72.

17. Zaccardi F, Webb DR, Yates T. Pathophysiology of type 1 and type 2 diabetes mellitus: a 90-year perspective. Postgraduate Medical Journal; 2015: 133-281. 